\title{
GAMBARAN PENGETAHUAN IBU TENTANG MAKANAN PENDAMPING ASI DI WILAYAH KERJA PUSKESMAS MAMAJANG KOTA MAKASSAR
}

Description Of Mom's Knowledge About Breast Milk Supplementary Foods at Mamajang Public Health Center Area, Makassar City

Subriah, Vilastri, Khairun Nisa Lukman, Suciati Lust, Fitrianti

Prodi D IV Kebidanan Makassar Poltekkes Kemenkes Makassar

\begin{abstract}
Nutritional problems occur in every life cycle, starting in the womb, infants, children, adults and the elderly. The period of the first two years of life is critical, there is rapid growth and development. Nutritional disorders that occur in this period are permanent, cannot be recovered even though nutritional needs in the next period are met. WHO/UNICEF recommends giving complementary foods to breast milk (MP-ASI) from the age of 6 months to 24 months and continuing breastfeeding until the child is 24 months or older. The provision of MP-ASI is a process in which breast milk alone is not sufficient to meet nutritional needs, so other foods and drinks are needed that are given together with breast milk. The purpose of this study was to describe the knowledge of mothers about MP_ASI at the Posyandu in the Work Area of the Mangasa Health Center Makassar. This type of survey research is descriptive and aims to describe the knowledge of mothers in providing complementary feeding to infants aged 6-24 months at the Posyandu in the working area of the Mamajang Health Center Makassar. The study population was all mothers who had babies aged 6-24 months who were taken by purposive sampling technique, as many as 50 samples. The results obtained by respondents who have good knowledge are 33 respondents $(66 \%)$ and respondents with a low level of knowledge are 17 respondents (34\%) this study concludes that mothers who have good knowledge will understand the type and menu of food given to her baby. In addition, mothers can choose food ingredients in such a way to get the best menu.
\end{abstract}

Keywords: Complementary feeding, Infants aged 6-24 months,

\section{ABSTRAK}

Masalah gizi terjadi di setiap siklus kehidupan, dimulai sejak dalam kandungan, bayi anak, dewasa dan usia lanjut. Periode dua tahun pertama kehidupan merupakan masa kritis, terjadi pertumbuhan dan perkembangan yang pesat. Gangguan gizi yang terjadi pada periode ini bersifat permanen, tidak dapat dipulihkan walaupun kebutuhan gizi pada masa selanjutnya terpenuhi. WHO/UNICEF merekomendasikan pemberian makanan pendamping air susu ibu (MP-ASI) sejak bayi berusia 6 bulan sampai 24 bulan, dan meneruskan pemberian ASI sampai anak berusia 24 bulan atau lebih. Pemberian MP-ASI suatu proses dimana ASI saja tidak cukup untuk memenuhi kebutuhan nutrisi sehingga diperlukan makanan dan minuman lain yang diberikan bersamaan dengan ASI. Tujuan dari penelitian ini adalah untuk mengetahui gambaran pengetahuan ibu tentang MP_ASI di Posyandu Wilayah Kerja Puskesmas Mangasa Makassar. Jenis penelitian survey bersifat deskriptif bertujuan mengetahui gambaran pengetahuan ibu dalam pemberian makanan pendamping ASI pada bayi usia 6-24 bulan di Posyandu wilayah kerja Puskesmas Mamajang Makassar. Populasi penelitian adalah seluruh ibu yang mempunyai bayi usia 6-24 bulan yang diambil dengan teknik purposive sampling, sebanyak 50 sampel. Hasil penelitian diperoleh responden yang memiliki pengetahuan yang baik yakni 33 responden $(66 \%)$ dan responden dengan tingkat pengetahuan yang kurang yakni 17 responden (34\%) Kesimpulan penelitian ini yaitu ibu yang memiliki pengetahuan yang baik akan mengerti tentang jenis maupun menu makanan yang diberikan kepada bayinya. Selain itu ibu dapat memilih bahan makanan sedemikian rupa untuk mendapatkan menu terbaik.

Kata Kunci : Bayi usia 6-24 bulan, Makanan Pendamping Air Susu Ibu (MP-ASI)

\section{Pendahuluan}

Pembangunan kesehatan diarahkan untuk meningkatkan kualitas sumber daya manusia yang sehat dan mandiri, serta mempertinggi derajat kesehatan dan gizi masyarakat dalam rangka peningkatan taraf hidup, kecerdasan dan kesejahteraan rakyat pada umumnya. Peningkatan ini diupayakan melalui perbaikan kesehatan masyarakat yang meliputi perbaikan gizi, penyuluhan kesehatan, penyehatan lingkungan dan pelayanan kesehatan ibu dan anak (Depkes, 2010).

Nutrisi yang adekuat pada masa bayi dan anakanak sangat dibutuhkan untuk perkembangan setiap anak. Diketahui bahwa periode dari lahir hingga usia 2 tahun merupakan periode yang penting untuk 
mendapatkan pertumbuhan dan perkembangan (Dewi Lestari, 2012). Pertumbuhan dan perkembangan merupakan suatu proses pertumbuhan fisik yang ditandai bertambahnya ukuran organ tubuh karena pertumbuhan sel dan suatu proses aspek non fisik menuju terciptanya kedewasaan yang ditandai dengan bertambahnya kemampuan/ keterampilan yang menyangkut struktur dan fungsi tubuh. (Rukiyah Ai Yeyeh dan Yulianti Lia, 2013).

Masalah gizi terjadi di setiap siklus kehidupan, dimulai sejak dalam kandungan, bayi anak, dewasa dan usia lanjut. Periode dua tahun pertama kehidupan merupakan masa kritis, karena pada masa ini terjadi pertumbuhan dan perkembangan yang pesat. Gangguan gizi yang terjadi pada periode ini bersifat permanen, tidak dapat dipulihkan walaupun kebutuhan gizi pada masa selanjutnya terpenuhi (Depkes, 2010). WHO/UNICEF merekomendasikan empat hal penting yang harus dilakukan yaitu; memberikan air susu ibu kepada bayi segera dalam waktu 30 menit setelah bayi lahir, memberikan ASI secara eksklusif sejak lahir sampai bayi berusia 6 bulan, memberikan makanan pendamping air susu ibu (MP-ASI) sejak bayi berusia 6 bulan sampai 24 bulan, dan meneruskan pemberian ASI sampai anak berusia 24 bulan atau lebih (Depkes RI, 2006). Pemberian MP-ASI didefinisikan sebagai suatu proses dimana ASI saja tidak cukup untuk memenuhi kebutuhan nutrisi sehingga diperlukan makanan dan minuman lain yang diberikan bersamaan dengan ASI (Dewi Lestari, 2012).

Kenyataan di lapangan masih banyak ibu yang memberikan MP-ASI pada bayinya meskipun umurnya masih belum mencapai 6 bulan yang dapat mengakibatkan anak diare, produksi ASI berkurang karena anak sudah kenyang dan jarang menyusui, serta dapat menimbulkan alergi di kemudian hari karena usus bayi masih mudah dilalui protein asing. Terlalu lambat memberikan MP-ASI juga tidak baik karena ASI saja hanya bisa memenuhi kebutuhan bayi sampai 6 bulan. Sehingga pemberian MP-ASI Lebih dari itu kemungkinan bayi akan mengalami malnutrisi (Elvi N, 2007).

\section{Metode penelitian}

Jenis penelitian ini adalah penelitian survey yang bersifat deskriptif yang bertujuan mengetahui gambaran pengetahuan ibu dalam pemberian makanan pendamping ASI usia 6-24 bulan di posyandu wilayah kerja Puskesmas Mamajang Kota Makassar. Adapun variabel yang akan diteliti yaitu variabel independent yaitu makanan pendamping ASI. Variabel dependent yaitu pengetahuan. Lokasi penelitian adalah di posyandu wilayah kerja Puskesmas Mamajang Kota Makassar. Waktu Penelitian Penelitian dilakukan pada bulan Agustus-Oktober 2018. Populasi Yang menjadi populasi penenlitian adalah seluruh ibu yang mempunyai bayi usia 6-24 bulan yang ada di posyandu wilayah kerja Puskesmas Mamajang Kota Makassar. Sampel Pengambilan sampel dilakukan dengan teknik purposive sampling, menggunakan kriteria , ibu yang memiliki anak usia 6-24 bulan. Instrumen yang digunakan pada penelitian ini adalah kuesioner yang membahas tentang makanan pendamping ASI. Pengolahan dan analisis data yaitu dengan menggunakan bantuan data komputer. Sebelumnya semua data di analisis maka terlebih dahulu data yang telah diolah selanjutnya dianalisis secara deskriptif dengan menggunakan.

\section{Hasil dan Pembahasan}

a. Karakteristik Responden Karakteristik ibu meliputi umur, pendidikan dan pekerjaan

Tabel 5.1 Karakteristik responden berdasarkan umur, pendidikan dan pekerjaan Di Puskesmas Mamajang Kota Makassar

\begin{tabular}{lcc}
\hline Umur & $\begin{array}{c}\text { Frekuensi } \\
(\mathrm{n})\end{array}$ & Persen(\%) \\
\hline $16-20$ & 6 & 10 \\
$21-25$ & 8 & 16 \\
$26-30$ & 11 & 22 \\
$31-35$ & 16 & 32 \\
$36-40$ & 5 & 10 \\
$41-50$ & 4 & 8 \\
\hline \multicolumn{1}{c}{ Jumlah } & 50 & 100 \\
\hline Pendidikan & Frekuensi & Persen(\%) \\
\hline SD & 3 & 6 \\
SMP & 18 & 36 \\
SMA & 28 & 56 \\
SI & 1 & 2 \\
\hline Jumlah & 50 & 100 \\
\hline Pekerjaan & Frekuensi & Persen (\%) \\
IRT & 50 & 100 \\
\hline Jumlah & 50 & 100 \\
\hline \multicolumn{2}{c}{ Sumber: Data Primer 2018 }
\end{tabular}

Tabel 5.1. Menunjukkan bahwa responden tertinggi pada umur 31-35 tahun yaitu sebanyak 16 responden $(32 \%)$ dan responden terendah pada umur 41-50 tahun sebanyak (8\%), sedangkan pada tingkat pendidikan responden yang tertinggi pada tingkat pendidikan SMA yaitu 28 responden $(56 \%)$ dan terendah pada tingkat pendidikan S1 yaitu 1 responden (2\%). Dan responden pada tingkat pekerjaan IRT yang tertinggi 50 responden $(50 \%)$. 
b. Pengetahuan

Distribusi frekuensi pengetahuan tentang MP-ASI

Tabel 5.2. Distribusi Frekuensi pengetahuan responden Tentang MP-ASI di Puskesmas Mamajang Kota Makassar

\begin{tabular}{cccc}
\hline No & Pengetahuan & $\begin{array}{c}\text { Frek } \\
\text { uensi }\end{array}$ & $\begin{array}{c}\text { Present } \\
\text { ase } \\
(\%)\end{array}$ \\
\hline 1 & Baik & 33 & 66 \\
2 & Kurang & 17 & 34 \\
\hline Jumlah & & 50 & $100 \%$ \\
\hline
\end{tabular}

Sumber, Data Primer, 2018

Berdasarkan tabel diatas menunjukkan bahwa dari 50ibu balita di Puskesmas Mamajang kota Makassar yang tergolong pengetahuan baik sebanyak 33Responden $(66 \%)$ dan pengetahuan yang kurang sebanyak 17Responden (34\%).

\section{Pembahasan}

Berdasarkan hasil penelitian menunjukkan bahwa sebagian besar umur ibu antara 20-35 tahun. Menurut Winkjosastro (2009), umur 20-35 termasuk dalam umur reproduksi sehat. Sebagian besar pendidikan yang tertinggi pada SMA yaitu 28 orang (56\%). Menurut Soekanto (2012) bahwa salah satu faktor yang mempengaruhi pengetahuan adalah pendidikan. Pendidikan adalah suatu proses belajar yang berarti di dalam pendidikan itu terjadi proses pertumbuhan, perkembangan atau perubahan ke arah yang lebih dewasa, lebih baik dan lebih matang terhadap individu, kelompok atau masyarakat. Berdasarkan pekerjaan ibu, sebagian besar ibu rumah tangga berpengetahuan baik, hal ini dimungkinkan ibu rumah tangga mempunyai banyak waktu untuk mengakses informasi melalui media elektronik dan mengikuti kegiatan kemasyarakatan. Tingkat pengetahuan terdapat 50 responden (100\%) memiliki pengetahuan baik dan dipandang dari segi pendidikan 3responden SD, 18 responden SMP, 28 responden SMA, dan 1 responden S1. Hal ini dimungkinkan semakin tinggi pendidikan semakin baik akses informasi. Menurut sutrisno (2016) dalam buku Hasna M. Noor dan Asmawati Gasma (2017), membuat kategori tingkat pengetahuan seseorang menjadi dua tingkatan yang didasarkan pada nilai presentasi yaitu :

1) Tingkatan pengetahuan baik bila nilainya $\geq 62,5 \%$;

2) Tingkatan pengetahuan kurang bila nilainya $<62,5 \%$

Hasil penelitian Ayudani terang, 2012 lbu yang memiliki pengetahuan yang baik tentang makanan pendamping ASI (MP-ASI) akan mengerti tentang pemilihan jenis maupun menu makanan yang akan ia berikan pada bayinya. Selain itu, ibu dengan pengetahuan yang baik dapat memilih bahan makanan sedemikian rupa untuk mendapatkan menu terbaik sekaligus mengupayakan variasi menu agar anak tidak bosan sehingga akan mempengaruhi tingkat konsumsi. Tingkat konsumsi makan yang baik akan berdampak pada status gizi baik pula. Bayi yang mendapatkan MP-ASI pada umur yang tepat cenderung memiliki status gizi normal. Asupan makan yang dicerna dengan baik mencukupi kebutuhan gizi yang secara langsung membantu dan menjaga status gizi pada keadaan normal.

Dari hasil penelitian yang di peroleh bahwa penegetahuan ibu tentang pemberian makanan pendamping ASI pada bayi umur 6-24 bulan di wilayah kerja Puskesmas Mamajang Kota Makassar tahun 2018 masih kurang dimana dari 50 sampel yang diteliti yang memiliki pengetahuan yang baik yakni 33 Responden $(66 \%)$ dibandingkan dengan tingkat pengetahuan yang kurang yakni 17 Responden (34\%). Berdasarkan hasil tersebut menunjukan bahwa pada pengetahuan ibu tentang pemberian MP-ASI pada umur 6-24 bulan di wilayah kerja puskesmas Mamajang Kota Makassar tahun 2018 untuk tingkat pengetahuan sangat Baik. Hal ini sesuai dengan hasil penelitian yang menunjukan bahwa tingkat pengetahuan yang Baik lebih besar dari pada tingkat yang kurang. selain umur juga dipengaruhi oleh baik tidaknya penerimaan seseorang dalam menyikapi suatu informasi yang diperoleh serta melaksanakan suatu yang diinformasikan baik itu berupa saran, penyampaian, pengumuman, maupun penyuluhan. Pemberian MP-ASI harus bertahap dan bervariasi, mulai dari bentuk bubur cair ke bentuk bubur kental, sari buah, buah segar, makanan lumat, makanan lembek dan akhirnya padat, Pola pemberian MP-ASI sesuai dengan jenis makanan frekuensi makan dalam sehari yaitu mulai dari umur 6-9 bulan ASI sesering mungkin, sedangkan bubur susu dua kali sehari dua kali sehari, umur 9-12 bulan frekuensi makanan dalam sehari ASI sesring mungkin, bubur, buah, dua kali sehari, pada umur 13-24 bulan ASI dua kali sehari, makanan seperti orang dewasa seperti telur dan buahfrekuensinya 4-5 kali sehari.

Dengan respon yang baik maka ibu dapat mengaplikasikan anjuran-anjuran kesehatan yang menurut ibu baik bagi kesehatan, adapun anjuran yang diberikan oleh tenaga kesehatan yaitu : tentang pentingnya pemberian ASI saja sampai bayi berumur 6 bulan tanpa makanan pendamping, sedangkan jika penerimaan ibu tentang informasi kurang baik, menjadikan ibu tidak mau menerapkan informasi yang diberikan termasuk mengenai pemberian makanan pendamping ASI. Hal ini sesuai dengan teori yang mengatakan bahwa selain umur dan tingkat pendidikan, tingkat pengetahuan juga dipengaruhi oleh baik tidaknya 
penerimaan seseorang dalam menyikapi suatu informasi yang diterima dan melaksanakan sesuai dengan yang diinformasikan kepadanya.

\section{Kesimpulan}

Pengetahuan ibu tentang pemberian makanan pendamping ASI (MP-ASI) pada bayi umur 6-24 bulan di wilayah kerja Puskesmas Mamajang Kota Makassar tahun 2018 sebagian besar memiliki pengetahuan yang baik dan ibu mengerti tentang jenis maupun menu makanan yang diberikan kepada bayinya. Selain itu ibu dapat memilih bahan makanan sedemikian rupa untuk mendapatkan menu terbaik.

\section{DAFTAR PUSTAKA}

Depkes RI, 2006, Pedoman umum pemberian Makanan pendamping Air Susu Ibu (MP-ASI) Lokal

Depkes RI. (2010). Riset Kesehatan Dasar Tahun 2010. Penelitian dan Pengembangan Kesehatan Departemen Kesehatan $\mathrm{RI}$.

Depkes RI. 2006. Pedoman Umum Pemberian Makanan Pendamping Air Susu Ibu (MP-ASI) Lokal Tahun 2006. Jakarta : Departemen Kesehatan RI, Direktorat Jenderal Bina Kesehatan Masyarakat.

Elvi N, 2007, Gambaran Pengetahuan lbu tentang pemberian MP-ASI pada bayi usia 0-6 bulan, http://skripsikesehatan.blogspot.co.id/2011/05/gambaran-pengetahuan-ibu-tentang.html Diakses pada tanggal 16 Maret 2018

Ike Nurjanah, 2015, 01-gdl-ikenurjanah-899-1-ike_b. 12-8-2.pdf diakses pada tanggal 16 Maret 2016

Notoatmodjo, S. 2011. Kesehatan Masyarakat IImu Dan Seni. Jakarta : Rineka Cipta.

Nuhaeni, 2008. Pedoman Pemberian Makanan Pendamping ASI. Jakarta

Pancarani, 2017 Hubungan Pengetahuan dan Sikap ibu pada Informasi MP-ASI di Buku KIA dengan Pemebrian MP-ASI Balita Usia 6-24 Bulan di Kelurahan Bandarharjo Semarang Utara, http://eprints.undip.ac.id/55429/

Pujiadi, 2000. IImu Gizi Klinis pada Anak Balita. Balai Penerbit FK UI. Jakarta.

Rukiyah Ai Yeyeh, Yulianti Lia. 2013. Asuhan Neonatus Bayi dan Anak Balita. Jakarta Timur: CV. Trans Info Media.

Suhardjo, 2000. Pemberian Makanan Pada Bayi dan Anak. Yogyakarta: Kanisius.

Terang Ayudani, Gambaran Pengetahuan Ibu tentang MP-ASI dengan Ketepatan Waktu Pemberian MP-ASI dan Status Gizi Balita Usia 6-24 Bulan di Posyandu Permata Desa Baki Pandeyan Kabupaten Sukoharjo, 2012, http://eprints.ums.ac.id/21973/23/02._Naskah_Publikasi.pdf diakses tanggal 16 Maret 2018 